\title{
MODERN APPROACHES OF STUDENT'S SOCIAL HEALTH FORMATION IN THE PROCESS OF PHYSICAL EDUCATION
}

\author{
Viacheslav Babych ${ }^{1}$, Oleksandr Dubovoi ${ }^{2}$, Serhii Savchenko ${ }^{3}$, Vitalii Kurilo ${ }^{4}$, \\ Serhii Kharchenko ${ }^{5}$, Volodymyr Zaitsev ${ }^{6}$ \\ 1,2,3,4,5I 'Luhansk Taras Shevchenko National University', Ukraine \\ ${ }^{6}$ Chernihiv National Technological University, Ukraine
}

\begin{abstract}
Objective: to ascertain the influence of the updated Physical Education syllabus in the context offorming social health of secondary school students, as well as motivation of schoolchildren for Physical Education classes. Material: 457 school students (230 females and 227 males) of the $6^{\text {th }}$ and $7^{\text {th }}$ grades (aged 12-13) from different regions of Ukraine were respondents of the survey.

Method: observation, interviews and the authors' questionnaires ('Interest in Physical Education'with the use of customized tests by M. Ginzburg (Zaniuk, 2002), questionnaires 'value orientations' by M. Rokeach (Rozov, 2005), 'Orientation towards Increasing Social Health of a Person', as well as a questionnaire on the need of accomplishments by Yu. Orlov and Reyzas Assertiveness Schedule (Big Encyclopedia of Psychological Tests, 2007).

Results: It was discovered that in 2008-2009 only 23.7\% of schoolchildren liked physical education classes. Within this period of time, $18.5 \%$ of school students had a high level of orientation towards improving their own social health. The corrections made in 2012 to Physical Education syllabus contributed to an increase in the number of school students with a high level of motivation for Physical Education classes $(+41.7 \%)$, as well as the number of students who had a high level of orientation towards improving their own social health $(+23.3 \%)$. Positive changes were also recorded after the improvement of Physical Education syllabus in 2017 (under conditions of Physical Education reformation in Ukraine). The number of schoolchildren with a high level of motivation for Physical Education classes increased by 10.5\% compared with the results recorded in 2012-2016. The number of students aimed at improving their own state of social health increased by $17.1 \%$.

The content of Physical Education syllabus of years 2012 and 2017 has significant advantages over the syllabus of the Soviet times in the context of developing students' desire to be engaged in Physical Education on the whole and improve their own level of social health in particular. It is characterized by the improvement of the system of assessing schoolchildren's achievements in physical fitness, the option to increase the amount of time devoted to students' mastering various kinds of sports that are of particular interest to them, and the focus on providing schoolchildren with key life competencies.
\end{abstract}

Keywords: education system, reformation, schoolchildren, school subject 'Physical Education', social health.

To cite this article:

Babych, V., Dubovoi, O., Savchenko, S., Kurilo, V., Kharchenko, S., \& Zaitsev, V. (2021). Modern Approaches of Student's Social Health Formation in the Process of Physical Education. Education. Innovation. Diversity, 2(2), 16-23.

DOI: $\underline{\text { https://doi.org/10.17770/eid2021.1.5420 }}$

\section{Introduction}

The problem of forming a physically and mentally healthy person arose with the advent of human society and was in the process of formation, supplementation and reinterpretation over centuries (Iermakova, 2014). Up to now, this problem has been relevant not only in Ukraine but also in other countries of the world. Thus, scientists from Algeria (Kenioua \& Boumasjed, 2016) emphasize the importance of maintaining mental health of young students through their integration into various entertainment and competitive activities. Authors of the article 'Academic Youth's Health Behavior' (Radzimińska et al, 2016) lay stress on the implementation of health promotion programs for Polish students. The scientists note that the life style, habits and behaviour patterns of a person play an extremely important role in protecting his/her health. They also pay attention to the study of the peculiarities of psychological and social protection of children at the age of 12-14 (Liashenko et al, 2017). 
Within the frames of our research, we have also taken the scientific works that contain the analysis of the content of Physical Education syllabus in different countries of the world, including Physical Education syllabus in Poland (Turchyk et al, 2009), Physical Education in the US schools (Osadchaya, 2004), peculiarities of the organization of Physical Education in Canada and Germany (Danilova, 2010), Physical Education in West European countries (Saparhasimova \& Pluzhnov, 2017) into consideration.We also relied on previous research in the context of determining the impact of the updated physical education program on the level of motivation of students to exercise.

Education in Ukraine is being reformed now. The Ministry of Education and Science of Ukraine has developed foundations of the Education Standard 'The New Ukrainian School' (Hrynevych et al, 2016).Any educator, from teacher-practitioners to leading scholars of pedagogical science could join the process. It is worth noting that the best practices of the most developed countries of the world and Europe were taken into account when drawing up these extremely important legal and regulatory documents. Thus, in the academic year 2017-2018, the subject 'Physical Education' was taught on the basis of an updated syllabus in accordance with the reform of general secondary education in Ukraine.

The research objective is: to ascertain the influence of the updated Physical Education syllabus in the context of forming social health of secondary school students, as well as motivation of schoolchildren for Physical Education classes.

\section{Methods}

Participants. 457 school students (230 females and 227 males) of the $6^{\text {th }}$ and $7^{\text {th }}$ grades (aged 12-13) from different regions of Ukraine were respondents of the survey. The state of motivation of the schoolchildren for physical education classes and their desire to systematically raise their own level of social health were assessed with the help of a set of research methods: observation, interviews and the authors' questionnaires ('Interest in Physical Education'with the use of customized tests by M. Ginzburg (Zaniuk, 2002), questionnaires 'value orientations' by M. Rokeach (Rozov, 2005), 'Orientation towards Increasing Social Health of a Person', as well as a questionnaire on the need of accomplishments by Yu. Orlov and Reyzas Assertiveness Schedule (Big Encyclopedia of Psychological Tests, 2007).

The research objective is: to ascertain the influence of the updated Physical Education syllabus in the context of forming social health of secondary school students, as well as motivation of schoolchildren for Physical Education classes.

Mathematical and statistical processing. To compare the frequency distribution between students Pearson's chi-squared test $X^{2}$ was used. It allows juxtaposing two empirical distributions and concluding if they are consistent with each other.

\section{Results and discussion}

Within the framework of this research, it is important for us to carry out a content analysis of Physical Education syllabus at various stages of its improvement in 2012 and 2017, as well as to investigate its impact on schoolchildren according to two main indicators: orientation of school students towards the increase of their own level of social health by means of Physical Education (Indicator 1) and motivation of students for Physical Education (Indicator 2).In order to find out the impact of the updated Physical Education syllabus in the context of schoolchildren's orientation towards improving their own level of social health (in the process of Physical Education), as well as the motivation of students for attending Physical Education classes, we compared the results of the students 'questionnaires completed in 2008-2009 with the results obtained from questionnaires filled out in 2012-2016and in 2017-2018. These are 
the periods when some corrections were made to Physical Education syllabus in terms of its content.

The questionnaires, interviews and observations conducted allowed us to establish that in 2008-2009 (before the beginning of the reformation of Physical Education in Ukraine) only 23.7\% of school students liked Physical Education lessons, $28.9 \%$ liked them partially, $47.4 \%$ of schoolchildren did not like Physical Education at all. Similar results were received regarding the desire of schoolchildren to increase their own level of social health in the process of Physical Education. Thus, $18.5 \%$ of school students had a high level of orientation in the abovementioned context; $24.1 \%$ displayed partial orientation; and $57.4 \%$ of schoolchildren had lack of orientation towards the increase of their level of social health. Given the information above, we can see that the results obtained according to the above indicators correlate with each other. More than one-third of school students showed insufficient level of motivation for Physical Education classes and orientation towards improving their level of social health by means of Physical Education. Meanwhile, we will substantiate the reasons for such results later in the section 'discussion'.

We will focus on the analysis of Physical Education syllabus 2012 (developed by T.Krutsevych as the head of the editorial board). Unlike Physical Education in Soviet times, the improved Physical Education syllabus (2012) is based on a modular system. We can emphasize the syllabus positive changes in the context of raising school students' interest in Physical Education and social health. The thing is that since 2012 practically every kind of sports (within the frames of the subject 'Physical Education') can be an optional module. Thus, teachers of Physical Education can develop their own optional modules for this syllabus (Krutsevych et al, 2012), which have to undergo the process of verification. This is totally different from the requirements for a syllabus in Soviet times, where its content was strictly regulated.

The syllabus of 2012 also provides (at least, it is not excluded) an increase or decrease in the number of hours to study any module (kind of sports). Thus, in case most schoolchildren are interested in this or that kind of sports (football, basketball, etc.), the teacher can increase the number of hours for teaching it. Therefore, school students' desires and aspirations are again taken into account. Under these conditions, schoolchildren also have an opportunity to improve the level of technoque skills.

The change in approaches to assessing school students' achievements has a prominent role in the context of improvement of Physical Education syllabus. As it is noted in the syllabus, the following activities can be assessed in order to have a clear vision of schoolchildren's educational achievements in Physical Education classes:

1. Acquisition of a physical exercise technique (can be carried out independently from the educational standard).

2. Meeting the educational standard (taking into account the dynamics of individual results).

3. Performance of educational tasks in class.

4. Acquisition of theoretical and methodological knowledge.

We would like to put emphasis on the second point of the assessment of school children's educational achievements in Physical Education classes. It states that the assessment of the fact whether the tasks performed meet the educational standard takes into account the dynamics of individual results. At the same time, the mark received for meeting the educational standard is not the main during the thematic, semester or annual assessment. In our opinion, this is the key point in the context of forming social health of adolescents within the frames of this subject. Being focused on their own achievements, school students do not get disenchanted with themselves, their own willpower and abilities (the way it used to be in Soviet times when the standards were not met). On the contrary, even if a school child is not able to show high results when trying to meet this or that norm, he (she) will eventually be able to see the progress in the 
development of his (her) physical qualities, taking into account the dynamics of individual results. It also gives school students an impetus for further 'small' victories over themselves, and therefore directly affects the improvement of the state of social health of the schoolchildren.

Our research justifies the corrections made to the syllabus (2012). Thus, the number of students who liked physical education classes doubled, from $23.7 \%$ (in 2008-2009) to $65.4 \%$ (from 2012 to 2016). As we can see, the difference between the results was $+36.5 \%$, $(\mathrm{p}<0.05$ ). The number of schoolchildren who did not like classes significantly decreased, from $47.4 \%$ to $18.2 \%(-29.2 \%)$.

There also were significant positive changes to the number of students who had a high level of orientation towards raising their level of social health in the process of Physical Education. The number of students with a high level of such an orientation increased by $23.3 \%$ (from $18.5 \%$ to $41.8 \%, \mathrm{p}<0.05$ ). Instead, the number of schoolchildren with a low level decreased by $35.7 \%$ (from $57.4 \%$ to $21.7 \%$ ). From everything given above, we can also see that positive changes correlate with each other according to both indicators. This is especially relevant to the reduction of the number of schoolchildren with low level of interest (the first indicator) and low levels of orientation towards improving their own social health (the second indicator). The difference between them was only $6.5 \%$. Significantly greater differences were recorded regarding the number of schoolchildren with a high level of interest in physical education and orientation towards improving their social health. Namely $13.2 \%$ in favour of the first indicator (interest in physical education). Therefore, although the corrections made to the syllabus (2012) had a positive impact on both indicators, the positive changes in raising school students' interest in Physical Education were more significant.

Meanwhile, within the framework of this research, it was important for us to establish changes upon both of the indicators (in dynamics) after the corrections to Physical Education syllabus made in 2017. Firstly, we would like to analyse the corrections made to the syllabus in the context of the education system reformation in Ukraine. The content of Physical Education syllabus 2017 (revised in accordance with Order No. 52 of the Ministry of Education and Science of Ukraine dated 13January2017 and Order No. 201 dated 10 February 2017, the head of the editorial board being M. Tymchyk) is based on the acquisition of key vital competences by students. Within the scope of this publication, we will briefly turn to the analysis of those content segments of the syllabus that address the problems of forming social health of adolescents and increase the motivation of schoolchildren to be engaged in Physical Education. Thus, the content segment 'Environmental Safety and Sustainable Development' provides for the formation of social activity, responsibility and environmental awareness among school students, readiness to participate in solving environmental and society development problems, awareness of the importance of sustainable development for future generations. The content segment 'Civil Liability' also has a direct impact on the formation of social health of contemporary adolescents.

The implementation of this content segment (as it is indicated in the syllabus) is aimed at the formation of a responsible member of the community and society who understands the principles and mechanisms of the society functioning. These components are extremely important in the context of forming schoolchildren's social health. The same applies to the content segment 'Health and Safety', within the framework of which it is proposed to consider issues that involve the formation of a schoolchild as a spiritually, emotionally, socially and physically competent member of the society that can lead healthy lifestyle and create a safe living environment. The syllabus emphasises that with the help of this content segment,school students will realize that Physical Education is an important means of increasing social activity of people, satisfying their moral, aesthetic and creative needs, a vital urge to have mutual communication, to develop friendly relations, etc. There is a stress laid on the importance of conscious attitude of students to their own health and health of other people, the ability to 
organize a game or other type of motor activity, communicate in different situations of sports activities, defuse conflicts, achieve fair victory and admit defeat with dignity, ensure fair play, etc.

The results of the school student survey in 2018 showed that the content segments introduced into the revised Physical Education syllabus positively influenced schoolchildren's aspirations for increasing their own social health. This can be seen clearly if to compare this with the previous results of the school student survey. Thus, if in 2014 the number of students with a low level of orientation towards improving their social health was $21.7 \%$, then after the implementation of the revised Physical Education syllabus (in the context of reforming Physical Education in Ukraine in 2018), there were $12.4 \%$ of them (-9.3\%). The number of schoolchildren with a high level of such an orientation got comparatively increased from $41.8 \%$ of students in 2014 to $58.9 \%$ ( $+17.1 \%, \mathrm{p}<0.05)$.

We can also observe positive changes in the increase of the number of students who became more interested in Physical Education. From 65.4\% (2014) to 75.9\% in 2018 (+ 10.5\%, $\mathrm{p}<0.05)$.). There was a decrease in the number of schoolchildren who did not like Physical Education lessons to $9.7 \%$ from $18.2 \%$ in 2014 (-8.5\%). Repeatedly, we can see that positive changes were recorded upon both indicators with minor differences between them. The dynamics of changes of motivation of schoolchildren for attending the Physical Education lessons as well as their orientation towards improving their social health can be clearly seen with the help of the diagrams (Fig. 1 and 2).

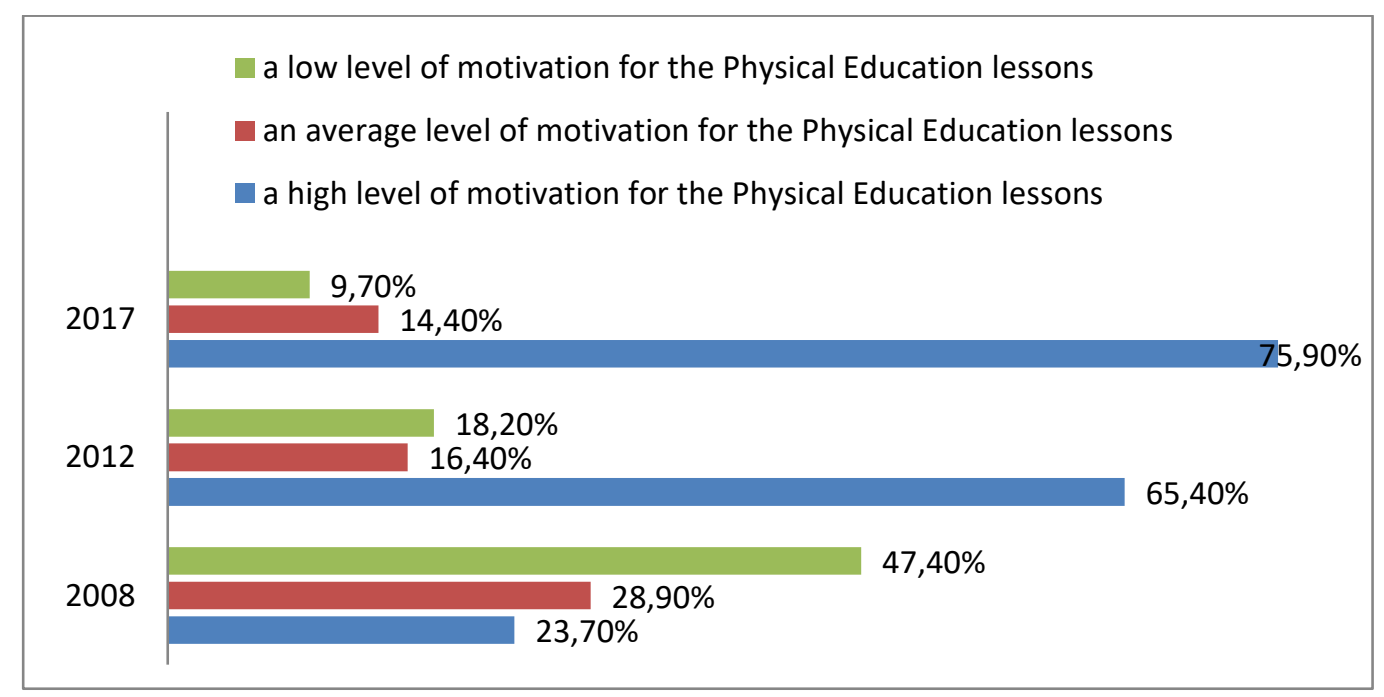

Figure 1 The dynamics of changes of motivation of schoolchildren for attending the Physical Education lessons 


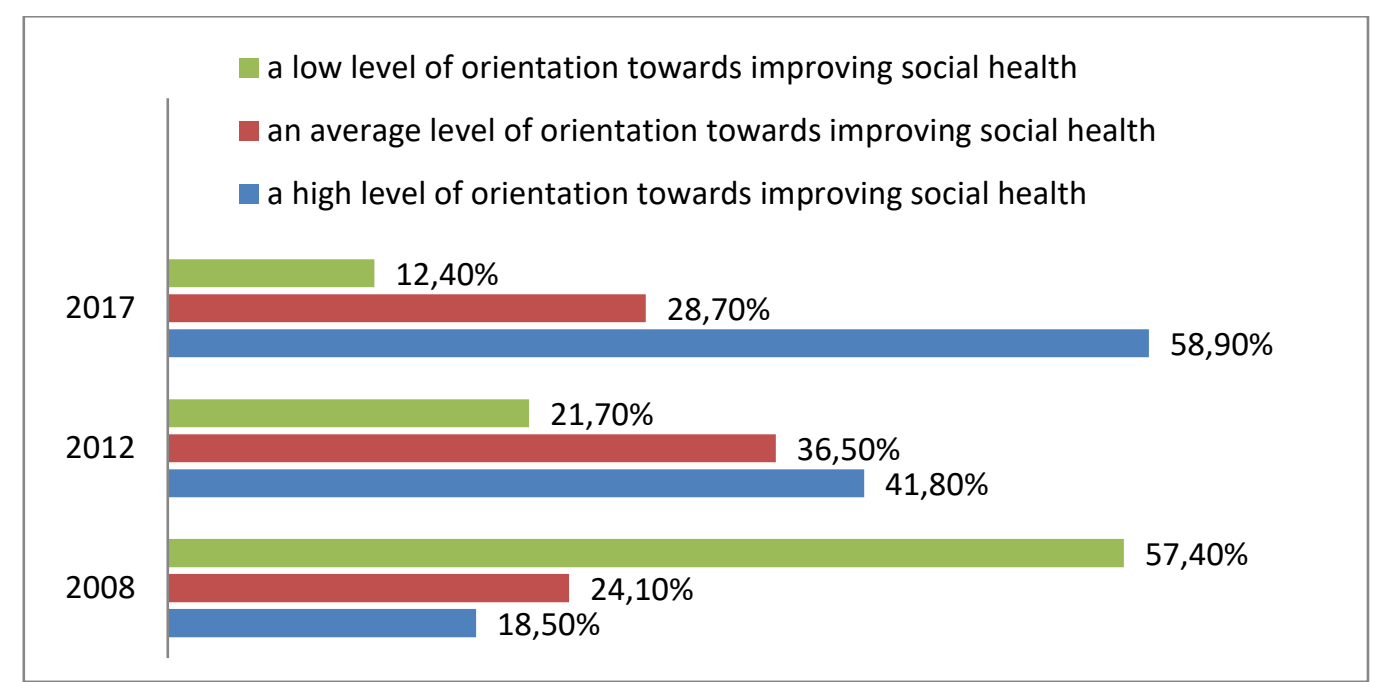

\section{Figure 2 The dynamics of changes of the level of orientation of schoolchildren towards improving their social health}

From the results of the research described above, we can see that their change in dynamics correlates with the existing changes in the content of the subject 'Physical Education'. The lowest indicators of the desire of schoolchildren to increase their own level of social health with the help of the possibilities provided by Physical Education, as well as the lowest rates of students' desire to attend this class, were observed until 2012.This is the period when the subject 'Physical Education' was taught according to the syllabus which was to a large extent based on the syllabus developed in Soviet times. Starting from 2012 up to 2016, the interest in this subject and the desire to raise their own level of social health among school students gradually increased. In 2018 (the next year after Physical Education syllabus was finalized in 2017), there was also a certain increase in the number of students who became more interested in Physical Education and aimed at improving their social health. This, in our opinion, took place due to strengthening the theoretical part of the syllabus in the context of raising awareness among schoolchildren about the formation and preservation of their own health, ensuring social activity by means of Physical Education, acquisition of the necessary vital competencies, etc. The justification of the corrections made to Physical Education syllabus is confirmed by other studies by E. Uvarov, M. Belaid, S. Yahiaoui. On analysing syllabi of Physical Education in schools of Europe, the authors have discovered that today, in the organization of Physical Education, it is necessary to focus on the balanced effect of both the motor and intellectual components of Physical Education (Uvarov et al, 2016). This also corresponds to the results of other studies, which state that one of the conditions for improving the motivation of school students to be engaged in Physical Education is to increase the level of knowledge in Physical Education (Kondakov et al, 2015). One of the most important benefits of the improved Physical Education syllabus of 2012 and 2017 is that, unlike it used to be done according to the Soviet syllabus, students are not forced to be involved in Physical Education. On the contrary, according to the concept of an updated syllabus, teachers are willing to persuade students of the importance of Physical Education. It is implemented through the improvement of the system of assessing schoolchildren's progressing Physical Education, creating conditions for improving knowledge in the context of the beneficial effects of Physical Education for a person, taking into account the desires of school students to master a particular kind of sports, etc.

The fact that there was a significant number of schoolchildren who did not like Physical Education lessons (until 2012) is substantiated by the content of the syllabus itself, which largely resembled Physical Education syllabus of the Soviet era. In Soviet times, neither desires of students nor facilities and resources or any other conditions and circumstances were taken 
into account when choosing different kinds of sports to be offered to schoolchildren for mastering within the frames of the subject 'Physical Education'. Thus, school students' identity and interests were ignored (by the system of Physical Education at the time), which, surely, negatively affected both schoolchildren's desire to attend Physical Education and the state of their social health. Meanwhile, this was not the worst thing that negatively influenced school students in this context. It should be noted that Physical Education classes in the Soviet era were permeated with 'drilling' a child. This, in its turn, constantly 'constrained 'school students, and did not allow them to fully enjoy the classes. Mastering any kind of sports (volleyball, basketball, etc.) was largely compulsory. Physical Education classes to a certain extent resembled a training session that should take place when preparing athletes in such institutions as children's sports school.

When providing characterisation of the assessment of school students' achievements in physical education (at the time), it is worth mentioning that, firstly, the educational standards of physical fitness were rather high for students. Secondly, when this standards were designed they almost ignored the height of a schoolchild (for example, when jumping over a 'pommel horse'), the weight (for example, when climbing up a rope), and other objective parameters that can somehow affect the performance. However, the assessment of schoolchildren's achievements in Physical Education (in Soviet times) for a term, or even an academic year, was based on the compliance with the standards of physical fitness. It is noteworthy that this did not take into account such aspects as students' diligence when mastering a particular technical element, their activity in class, theoretical knowledge, etc. There was almost no individual approach to a child within the frames of the educational process in Physical Education classes. Instead, a child who did not manage to comply with the standards, felt humiliated, awkward, and inferior. This, in its turn, negatively affected the students' desire to attend such classes, as well as the state of social health of the vast majority of schoolchildren.

\section{Conclusions}

Summing up everything given above, we can draw the following conclusions:

1) The lack of an individual approach to personality within the educational process, coercion, unreasonably high standards of assessing achievements in Physical Education were the main negative manifestations of Physical Education in Soviet times. This, in its turn, had a very negative impact on schoolchildren's desire to be engaged in Physical Education, as well as on the state of their social health.

2) The syllabus of 2012 stipulates the improvement of the system for assessing the achievements of schoolchildren in Physical Education, taking into account possibilities for increasing the time for mastering the kinds of sports that schoolchildren are interested in. As a result, it significantly influenced the schoolchildren's desire to be engaged in Physical Education, as well as on the state of their social health.

3) The content of the updated Physical Education syllabus (2017) has an enormous potential for providing schoolchildren with knowledge on the improvement of somatic and social health. The benefit of the revised syllabus (in terms of reforming Physical Education in Ukraine), as compared to the syllabus 2012, is also its focus on providing schoolchildren with key life competencies.

\section{References}

Big Encyclopedia of Psychological Tests (2007). Moscow: Eksmo.

Danilova, L. (2010). Physical Education of Schoolchildren in Canada, Germany and USA or How to Win Olympics, Volume 5, 2-7. Yaroslavl State Pedagogical University. Yaroslavl. 
Iermakova, T. (2014). Development of the idea of forming health culture of a person in the world educational thought. Pedagogics, psychology, medical-biological problems of physical training and sports, Volume4, Issue 18, 8-12. DOI: https://doi.org/10.6084/m9.figshare.950949

Kenioua, M. \& Boumasjed, A. (2016), Sport and mental health level among university students. Physical Education of Students, Volume 3, Issue 20, 39-42. DOI: https://doi.org/10.15561/20755279.2016.0305

Kondakov, V., Kopeikina, E., Balysheva, N., Usatov, A., \& Skrug, D. (2015). Causes of declining interest of students to employment physical education and sports. Physical education of students, Volume1, Issue 19, 17-21. DOI: https://doi.org/10.15561/20755279.2015.0103

Liashenko, V., Tumanova, V., Gnutova, N., \& Gnutov E. (2017). Special aspects of 12-14 yrs children's psychological protection. Pedagogics, psychology, medical-biological problems of physical training and sports, Volume 4, Issue 21, 180-184. DOI: https://doi.org/10.15561/18189172.2017.0406

Osadchaya, T. (2004). The System for Monitoring Students' Achievements in Physical Education in the US Schools. Physical Education of Students, Volume2, 68-78.

Physical Education Syllabus for Grades 5-9 of Secondary School (2017). Retrieved from: https://osvita.ua/school/program/program-5-9/56135

Physical Education Syllabus for Grades 5-9 of Secondary School (2012). Kyiv.

Radzimińska, A., Weber-Rajek, M., Lulińska-Kuklik, E., Kaźmierczak, U., \& Moska, W. (2016). Academic youth's health behavior. Physical education of students, Volume 6, Issue 20, 55-62. DOI: https://doi.org/10.15561/20755279.2016.0607

Rozov, V.I. (2005). Adaptive Anti-stress Psychotechnologies: Teach. Manual. Kyiv: Kondor. Saparhasimova, A. \& Pluzhnov, A.(2017). Physical Education and Sports in West European Countries. Scientific Research. Retrieved from: http://repo.kspi.kz/bitstream/handle/item

The Law of Ukraine 'On Education' (2017). Kyiv. Retrieved from: http://w1.c1.rada.gov.ua

The New Ukrainian School: the Basic Concepts of the Standard of Education (2016). Lviv. Retrieved from: http://nus.org.ua

Turchyk, I., Vaceba, O., \& Biriuk, S. (2009). Physical Education Class in the System of Primary School Education of Poland. Young Sport Science of Ukraine, Volume 2, 187-191.

Uvarov, E., Belaid, M., \& Yahiaoui, S. (2016). The Content of the Physical Education Programs in Schools of Europe and Russia. Bulletin of Tambov University. Series: Humanities. Retrieved from: https://cyberleninka.ru

Zaniuk, S. (2002). Psykholohiia motyvatsii. Navchalnyi posibnyk. K.: Lybid. 